\title{
The Role of Agronomic Practices on Soil and Water Conservation in Ethiopia; Implication for Climate Change Adaptation: A Review
}

\author{
Amisalu Milkias Misebo \\ ${ }^{1}$ School of Natural Resource Management and Environmental Sciences, Haramaya University, Dire Dawa, \\ Ethiopia \\ Correspondence: Amisalu Milkias Misebo, School of Natural Resource Management and Environmental \\ Sciences, Haramaya University, P.O. Box, 138, Dire Dawa, Ethiopia. Tel: 251-912-719-143. E-mail: \\ amsalumilkias@yahoo.com; amsemilke@gmail.com
}

Received: January 19, 2018

Accepted: March 8, 2018 Online Published: May 15, 2018

doi:10.5539/jas.v10n6p227

URL: https://doi.org/10.5539/jas.v10n6p227

\begin{abstract}
Now, soil erosion, loss of soil fertility, and land degradation due to climate change has been pushing to search for more sustainable systems. Soil and water conservation practice contribute high in the long term agricultural sustainability and sustainable agricultural farming. The objective of this paper is to review the major agronomic practices and their role in soil and water conservation. The review revealed that the major agronomic soil and water conservations practices in Ethiopia are strip cropping, mixed cropping, intercropping, fallowing, mulching, contour ploughing, crop rotation, conservation tillage and agroforestry. The plant canopies, litter and mulching intercept rain by decreasing the amount, intensity and the spatial distribution of the precipitation reaching the soil surface and this protects the soil surface from the direct impact of raindrops which can cause a splash and sheet erosion. In soil and water conservation, this practice is higher than others, because crops and leguminous woody perennials improve and enrich soil conditions by atmospheric nitrogen fixation, an addition of organic matter through litterfall and dead and decaying roots, nutrient cycling, modification of soil porosity and contribution to infiltration rates. It also alleviates and maintains salinity, alkalinity, acidity and waterlogging problems. Hence, the use agronomic practices for soil and water conservation is vital for climate change adaptation and mitigation because it can give both productive role (producing food, fodder, fuel, wood) and protective role (soil conserving functions, windbreaks and shelterbelts).
\end{abstract}

Keywords: agronomic practices, soil and water conservation, soil erosion, climate change

\section{Introduction}

Land degradation is a major problem that requires urgent intervention measures. This is especially true in the poorest countries, where agricultural production is crucial to development, and the livelihoods of the majority of the population depend on the primary sector (Barbier \& Bishop, 1995). According to UNCCD (2004), six million hectares of productive land was being lost globally every year since 1990, due to land degradation. Majority of the population in East Africa is relying on agriculture for their survival. And yet with the changing climate, agricultural land use often results in the degradation of natural soil fertility and reduced productivity (Barbier \& Bishop, 1995), especially with increasing population that keeps putting more pressure on the land. The growing population all over the world force farmers to cut forests and cultivate marginal lands which result in the reduction of productivity with many tragic consequences on land (Milder et al., 2011).

In Ethiopia, the problem of land degradation especially soil erosion and depletion of nutrients is a critical environmental crisis (FARM-Africa, 2005). Following this, the natural resource has become increasingly depleting, rapid land conversion takes place and resulting unsustainable land management and land degradation (Zeleke, 2010). The question of soil conservation becomes most crucial because the soil is very easily eroded within no time. At the same time, it should be remembered that it takes hundreds of years to form one centimeter thick layer of soil (Morgan, 2005). Most of the cultivated lands are slopping and require one or more types of soil and water conservation measures. The topography and agro-climatic conditions are also varying; that one should have the ability to discern what type of soil and water conservation measures a particular land area requires (FAO, 1984). Most of the cultivated land needs application of long-term soil and water conservation 
measures followed by reorganization of land use pattern efficiently including soil moisture conservation, improvement of soil productivity and cropping and farming systems (Josh et al., 1999).

There are different ways of conserving soil and water. Generally, they are mechanical, biological and agronomic soil and water conservation (Tidemann, 1998; Morgan, 2005; FAO, 1984). The soil conservation measures adopted in the cropping systems and practices are called agronomic measures (Morgan, 2005). Agronomic conservation measures function by reducing the impact of raindrops through interception and thus reducing soil erosion and increasing infiltration rates, and also reducing surface runoff and soil erosion (Tidemann, 1996). There are a number of the agronomic measures of soil and water conservation. However, not all practices are suitable or practical in all the places under all the agronomic practices.

In order to mitigate climate change, water shortages, worsening soil conditions, and drought and desertification, promotion of soil and water conservation technologies have been suggested as a key adaptation strategy for countries in the developing world, particularly in sub-Saharan Africa (Kato et al., 2009). However, research studies show that "one-size-fits-all" recommendations on soil and water conservation technology suitability for specific locations are not appropriate depending on local conditions and circumstances. If sustainable land management technologies are to be adopted sustainably and if they are to produce the desired impacts on productivity and other desired aspects, there is still need for rigorous research on what and where particular land management interventions are likely to be successful (Kassie et al., 2010). Therefore, the aim of this paper is to review commonly applied agronomic soil and water conservation practices and its' role in soil and water conservation for climate change adaptation.

\section{The concept of Agronomic Practices}

There are numerous definitions and concepts of agronomic practices available in the literature. The agronomic measures are referred by the practices of growing vegetables on mild sloppy lanks to cover them and to control the erosion from there in living vegetation above the soil surface dissipates the crave the power of agents either they are water or wind (Tidemann, 1998). In case of water erosion it affects by several ways such as by enhancing infiltration rate and thereby reducing runoff velocity to scour the soil particles screening the eroded particles to reach them into the channels or reservoirs; by dissipating the kinetic energy of falling raindrops and thus reducing the splash erosion (Morgan, 2005).

According to FAO (1984), agronomic measures is that vegetation is used, either alive or dead, in sufficient quantities to shield the soil surface from the direct impact of raindrops and to create a rough surface which will physically impede run-off and slow it down to non-erosive velocities. The role of agronomic measures in achieving of soil \& water conservation has immense importance. It is important to understand and disseminate the different soil management practices used to cultivate the soil and grow the crops (Lynden \& Lane, 2004).

Agronomic or biological measures utilize the role of vegetation in helping to minimize the erosion by increasing soil surface cover, surface roughness, surface depression storage and soil infiltration (Noordwijk \& Verbist, 2000). According to Simpson (2010), agronomic practices are measures undertaken within the cropping area for crop production purposes and include practices such as intercropping, contour cultivation, minimum tillage, mulching, manuring, etc., which are usually associated with annual crops, are repeated routinely each season or in a rotational sequence, are of short duration and not permanent, do not lead to changes in slope profile, are not zoned and are independent of slope.

\section{Types of Agronomic Practices}

The major agronomic soil and water conservations practices in Ethiopia are: Strip cropping, mixed cropping, intercropping, fallowing, mulching, contour ploughing, crop rotation, conservation tillage, and agroforestry (Mati, 2005).

Strip Cropping: It is a kind of agronomical practice, in which ordinary crops are planted or grown in form of relatively narrow strips across the land slope (Figure 1). These strips are so arranged, that the strips crops should always be separated by strips of close-growing and erosion resistance crops. Strip cropping checks the surface runoff and forces them to infiltrate into the soil, which facilitates the concentration of rainwater (Morgan, 2005). 


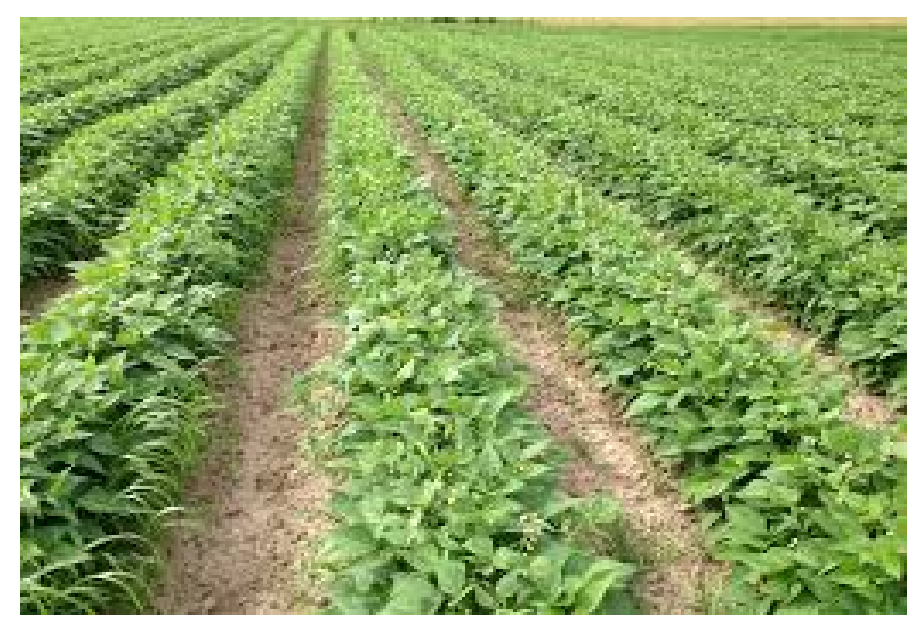

Figure 1. Strip cropping

Improved Fallow Systems (IFS): Arable lands are planted with food crops for some years and then the land is fallowed for some time to allow the soil to rejuvenate (Meine \& Bruno, 2000) (Figure 2). To shorten the fallow period, the area can be seeded with leguminous trees. Once the soil has been rejuvenated, the trees are cleared for crops. This can be considered as an improved version of the traditional shifting cultivation (Burgers et al., 2005).

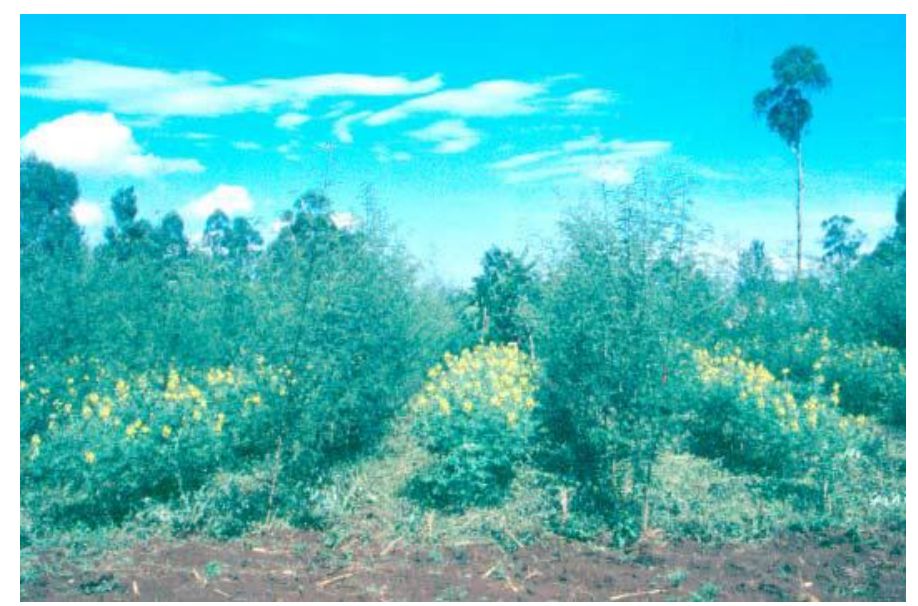

Figure 2. Improved fallow systems (IFS)

Natural Vegetative Strips (NVS): When land is ploughed along contour lines, certain strips of $40-50 \mathrm{~cm}$ wide are left unploughed, across the field on the contour (Garrity et al., 2004) (Figure 3). The natural vegetation of the strips filters the eroded soils, slows down the rate of water flow, and enhances water infiltration, making them very effective for soil and water conservation. Researchers found that these natural vegetative contour strips have many desirable qualities (Garrity et al., 2004). 


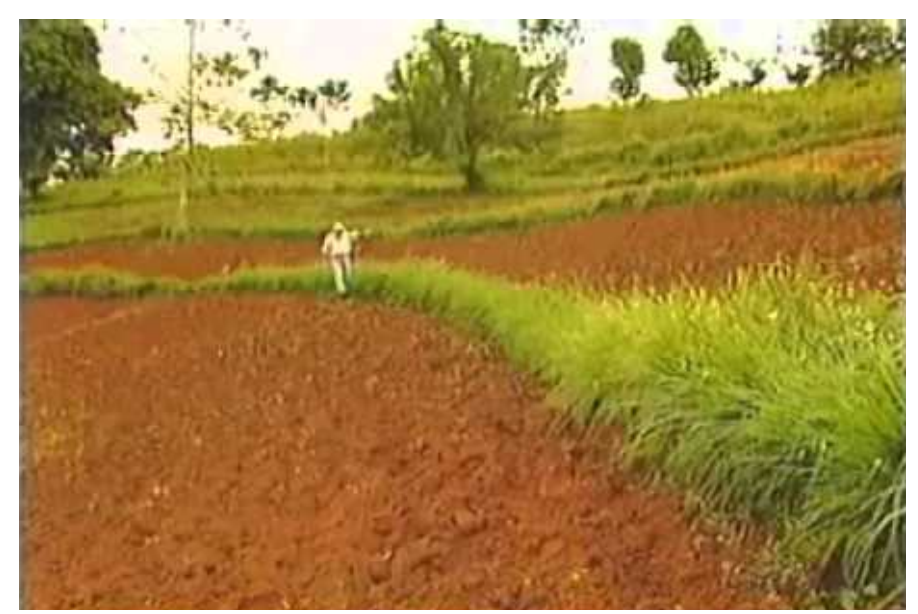

Figure 3. Natural vegetative strips (NVS)

Contour Tillage: It refers to all the tillage practices, mechanical treatments like planting, tillage and intercultural performed nearly on the contour of the area applied across the land slope (Meine \& Bruno, 2000) (Figure 4). It involves ploughing, planting and weeding along the contour, i.e., across the slope rather than up and down (Morgan, 2005). It also conserves soil, and due to increased time of concentration, more rainwater seeps through the soil profile to recharge groundwater. Summer ploughing leaves the soil highly absorbent of initial rains (Deborah, 2003).

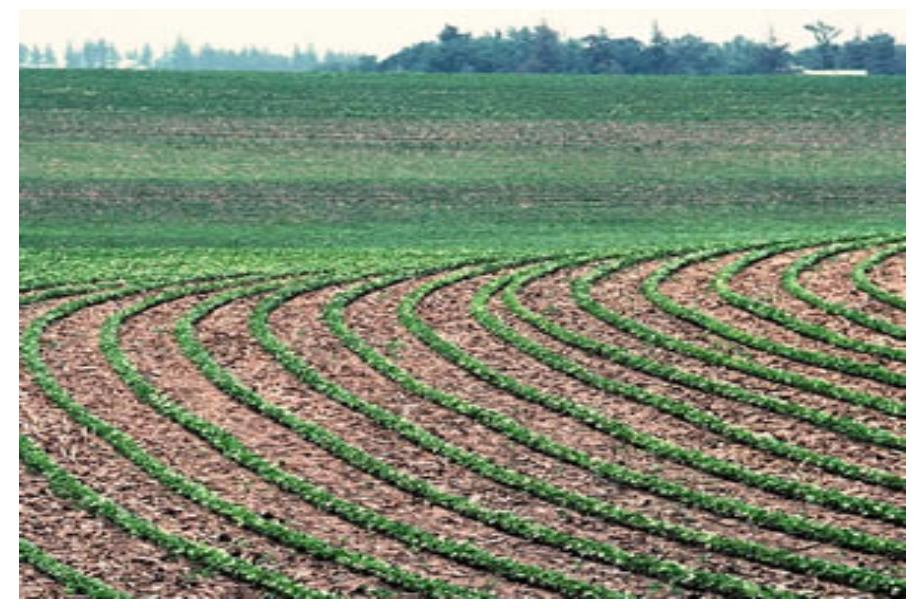

Figure 4. Contour tillage

Mixed/Intercropping: Intercropping is the cultivation of two or more crops at the same time in the same field (Meine \& Bruno, 2000; Andersen, 2005) (Figure 5). A wide range of crops can be used for intercropping. Mixed cropping of different crops along with the main crops, such as millets and different legumes, is an insurance against the climate change. The different root systems of mixed crop feed at different depths of the soil. Moreover, mixing cropping provides small quantities of a grain of different kinds of home consumption at different times (Morgan, 2005). 


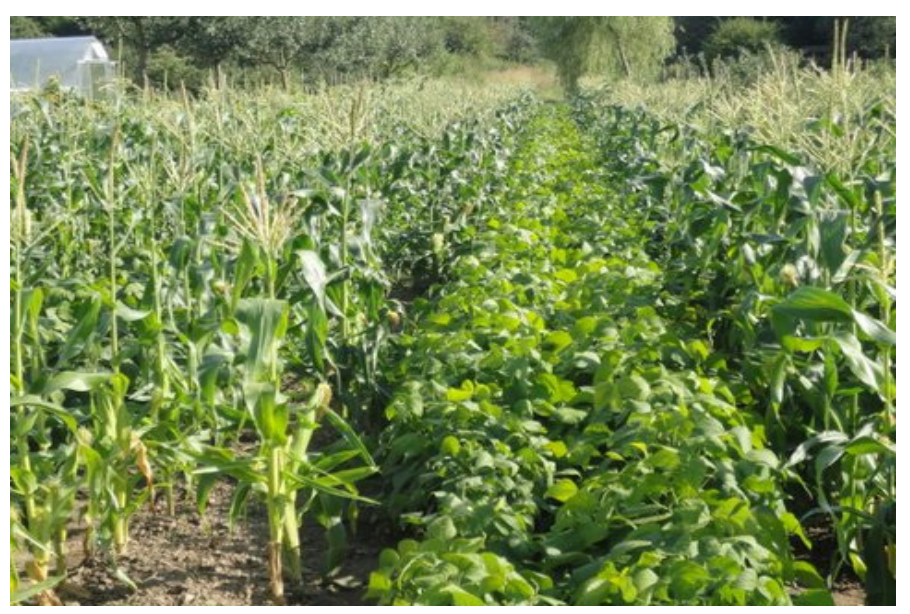

Figure 5. Mixed/Intercropping

Mulching: Mulches are ground covers that prevent the soil from being washed away, reduce evaporation, increase infiltration, and control growth of unwanted weeds (Deborah, 2003) (Figure 6). Mulch can be organic crop residue, pebbles, or materials such as polythene sheets. Mulching prevents the formation of the hard crust after each rain. Organic mulches add plant nutrients to the soil upon decomposition.

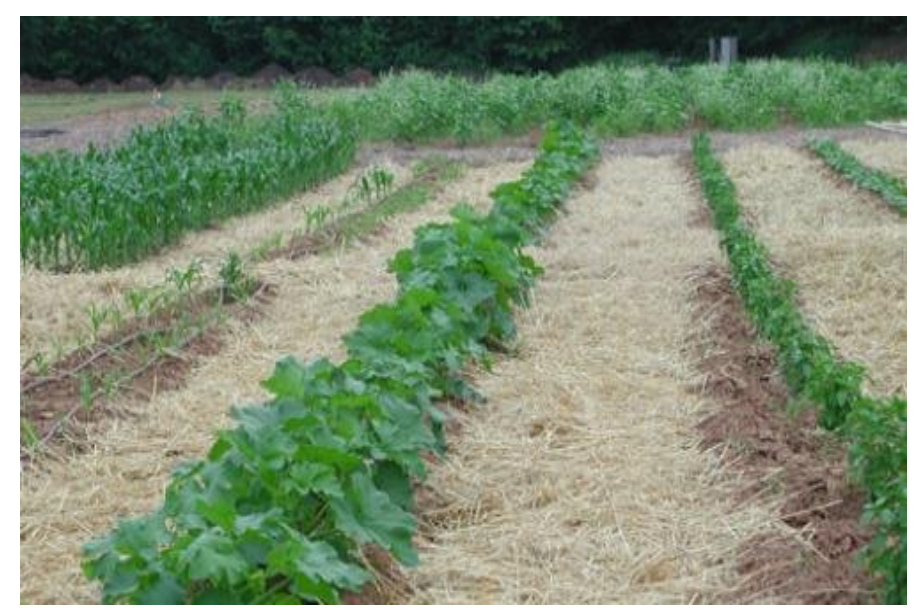

Figure 6. Organic grass mulch

Conservation Tillage: Is any method of soil cultivation that leaves the previous year's crop residue on fields before and after planting the next crop to reduce soil erosion and runoff, as well as other benefits such as carbon sequestration (Figure 7). The method tries to reduce labor in land preparation through tillage systems that promote soil fertility and soil water conservation. Conservation tillage applying four main principles: 1) zero or minimum soil turning, 2) permanent soil cover, 3) stubble mulch tillage, and 4) crop selection and rotations (Biamah et al., 2000). 


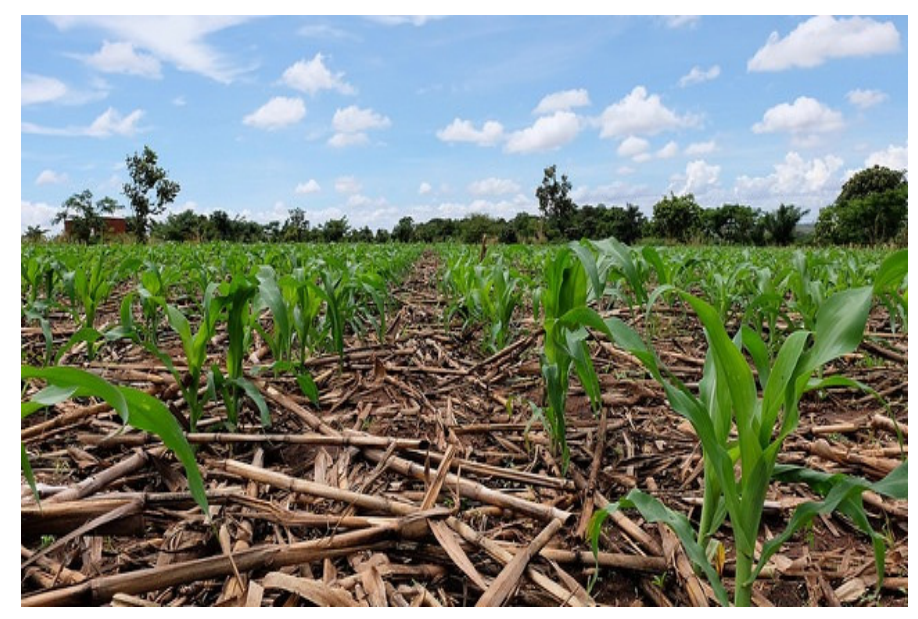

Figure 7. Conservation tillage

Agroforestry $(A F)$ : It refers to a system of land uses in that there are different trees or shrubs are grown in association with different agricultural crops, pastures or livestock (Figure 8). In relation to this, one of the most important feature of AF is that there are both ecological and economic interactions between the trees and other components (Young, 1989) such nature of integration of trees and shrubs in the land-use system can be either a spatial arrangement, or in a time sequence, e.g. trees growing in a field at the same time as a crop, or shrubs grew on a fallow for restoration of soil fertility. This is the most common practice in Sidam and Gedio Zone, Southern Ethiopia.

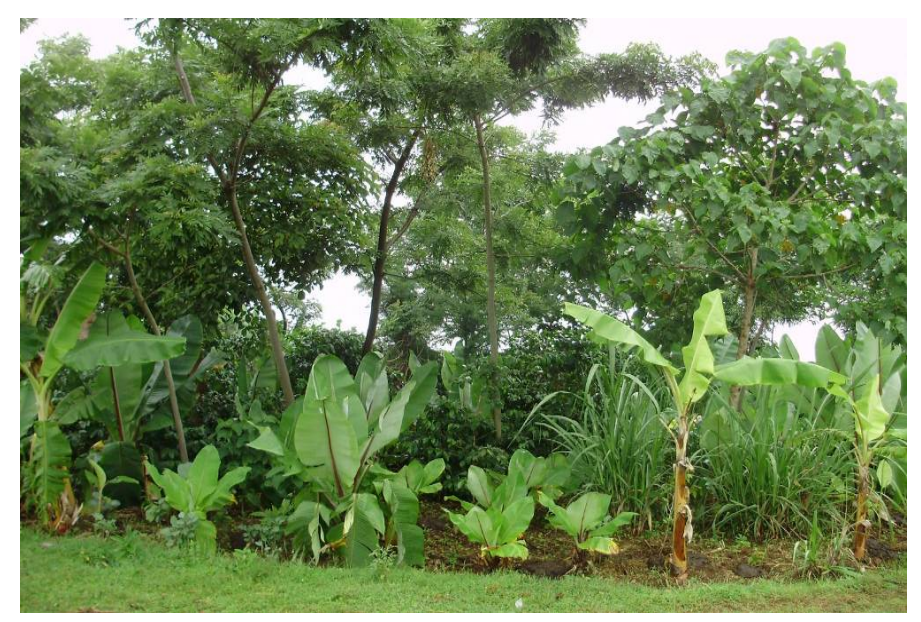

Figure 8. Agroforestry system

Crop Rotation: It involves alternating cereal crops with legume, pulse or oilseed crops (Figure 9). This type of rotation produces differing amounts and types of residue thus make crop residue and trash management easier. Therefore, a rotation is the key to success in reduced tillage systems, reduces soil erosion and then climate change adaptation (Ailincai et al., 2009). 


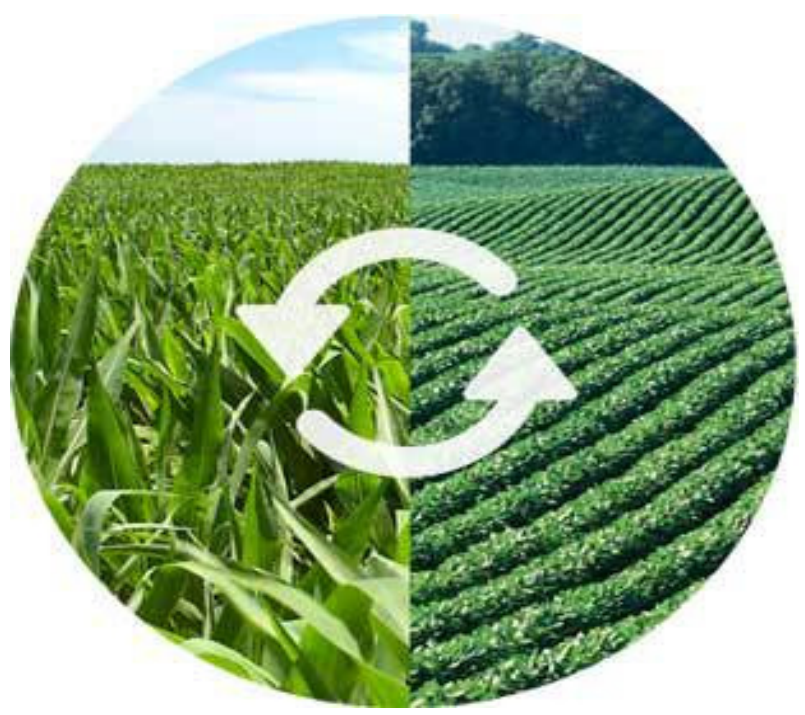

Figure 9. Crop rotation

\section{The Role of Agronomic Practices on Soil and Water Conservation (SWC)}

As it is known, soil and water conservation is not only to indicate keeping the soil in its place from erosion but also to maintain the soil fertility (Morgan, 2005; Young, 1989). For doing so, SWC requires control of erosion, maintenance of organic matter and soil physical properties, maintenance of nutrients, and avoidance of toxicity (Young, 1989). Therefore, in soil and water conservation point of view agronomic practices provide a protective role. This is by its prevention of soil from loss by its plant canopy, litter effect, and reduction of velocity of runoff mechanically by runoff barrier function (Young, 1989; Kilewe et al., 1988).

This can be viewed in its interception effect, i.e. the plant canopies, litter and mulching intercept rain by decreasing the amount, intensity and the spatial distribution of the precipitation reaching the soil surface (Kilewe et al., 1988). This protects the soil surface from the direct impact of raindrops which can cause a splash and sheet erosion, a breakdown of the soil structure, sealing of the surface and reduction of infiltration rates (Morgan, 2005; Young, 1989).

For example, in the tropics, home garden by their multilayer strata effect, they reduce soil erosion more than monocultures (Steppler \& Nair, 1987). The study by Kariaga (2004) indicated that runoff under sole maize is $67.6 \%$ of bare ground, while maize inter-cropped with cow-peas is only $14.3 \%$ that of bare ground. This means there is 4.73 times more runoff under maize as a mono-crop than under maize inter-cropped with cow-peas. The study by Lal (1998) indicated that for maize and soybean soil erosion was $511 \mathrm{~kg} / \mathrm{ha}$ for $4 \mathrm{Mg} / \mathrm{ha}$ mulch rate, 626 $\mathrm{kg} / \mathrm{ha}$ for $3 \mathrm{Mg} / \mathrm{ha}$ mulch rate, $841 \mathrm{~kg} / \mathrm{ha}$ for $2 \mathrm{Mg} / \mathrm{ha}$ mulch rate, $963 \mathrm{~kg} / \mathrm{ha}$ for $1 \mathrm{Mg} / \mathrm{ha}$ mulch rate, $994 \mathrm{~kg} / \mathrm{ha}$ for $0 \mathrm{Mg} / \mathrm{ha}$ mulch rate, and $3836 \mathrm{~kg} / \mathrm{ha}$ for plow till treatment. This means that the higher the mulching rate, the distinct the reduction in soil erosion would be. Also, Lal (1975) reported that soil loss reduced by $97 \%$, compared to soil loss in un-mulched plots. Ailincai et al. (2009) on $16 \%$ slope fields, the use of peas-wheat-maize rotation + two outside fields, cultivated with perennial grasses, determined the diminution by $40.2 \%$ (1.291 $\mathrm{t} / \mathrm{ha})$ in the mean annual losses of eroded soil.

The use of grass strip, farmyard manure and mulch reduced the rate of soil erosion by 79,12 and $98 \%$, respectively; and reduced runoff by $42,8.8$ and $75.5 \%$, respectively, than without (SCRP, 2000; Herweg \& Ludi, 1999; Birru et al., 2012; Araya \& Stroosnijder, 2010). The use of appropriate mulching material reduced soil erosion up to $98 \%$. The main reason for the effectiveness of mulch in reducing soil loss is that it prevents soil detachment by raindrops and thereby the amount of soil transported by the run-off. 
Table 1. The impact of some agronomic soil and water (SWC) practices on surface runoff in Ethiopia

\begin{tabular}{lllllll}
\hline SWC practices & $\mathrm{N}$ & $\begin{array}{l}\text { With } \\
(\mathrm{mm})\end{array}$ & $\begin{array}{l}\text { Without } \\
(\mathrm{mm})\end{array}$ & $\begin{array}{l}\text { Change } \\
(\mathrm{mm})\end{array}$ & $\begin{array}{l}\text { Change } \\
(\%)\end{array}$ & Reference \\
\hline Grass strip & 34 & 81.2 & 140.0 & -58.8 & 42 & SCRP, 2000; Herweg \& Ludi, 1999 \\
FYM* & 3 & 36.2 & 39.7 & -3.3 & 8.8 & Birru et al., 2012 \\
Mulch & 9 & 8.7 & 35.5 & -26.8 & 75.5 & Araya \& Stroosnijder, 2010; Birru et al., 2012 \\
\hline
\end{tabular}

Note. ${ }^{*} \mathrm{FYM}=$ Farm Yard Manure.

Table 2. The impact of some agronomic soil and water (SWC) practices on soil erosion in Ethiopia

\begin{tabular}{lllllll}
\hline SWC practices & $\mathrm{N}$ & $\begin{array}{l}\text { With } \\
(\mathrm{mm})\end{array}$ & $\begin{array}{l}\text { Without } \\
(\mathrm{mm})\end{array}$ & $\begin{array}{l}\text { Change } \\
(\mathrm{mm})\end{array}$ & $\begin{array}{l}\text { Change } \\
(\%)\end{array}$ & Reference \\
\hline Grass strip & 30 & 5.9 & 28.3 & -22.4 & 79 & SCRP, 2000; Herweg \& Ludi, 1999 \\
FYM & 3 & 8.6 & 9.8 & -1.2 & 12 & Birru et al., 2012 \\
Mulch & 3 & 0.2 & 9.8 & -9.6 & 98 & Birru et al., 2012 \\
\hline
\end{tabular}

Note. ${ }^{*} \mathrm{FYM}=$ Farm Yard Manure.

In many places it is known that the capacity of agronomic practice in controlling erosion is high in litter effect than canopy effect (Young, 1989). Crops and leguminous woody perennials improve and enrich soil conditions by atmospheric nitrogen fixation, an addition of organic matter through litterfall and dead and decaying roots, nutrient cycling, modification of soil porosity and contribution to infiltration rates (Nair, 1993). The effect of the tree species of an agronomic practice upon the nutrients of a site depends upon the balance between the uptake of nutrients by the biomass and the recycling of these nutrients to the soil (Batish et al., 2008).

According to Nair (1993), the beneficial effect of the tree within agronomic practice on soil can be seen as input, output, catalyst and turnover. When saying input it includes augments that is added like that maintenance or increase of soil organic matter through carbon fixation in photosynthesis and its transfer via litter and root decay, nitrogen fixation by some leguminous and a few non-leguminous trees, nutrient uptake, atmospheric input, and facilitation of growth-promoting substances by the rhizosphere (Young, 1989). The organic matter from biomass fallen down would decompose by decomposer groups. The organic matter content is one of the most important components of soil fertility that can influence soil properties (water holding capacity, stabilization, aggregation) and affect the availability of nutrients (against leaching). For example the cation exchange capacity and nutrient availability are dependent on OM especially in soils dominated by low-activity clays such as kaolinite. Organic substances in OM can increase the solubility of phosphorus in the soil and reduce phosphorus fixation by competing with phosphate ions for sorption sites such as oxides of iron and aluminum and clay minerals (Nair, 1993; Young, 1989).

The second is output. This indicates the removal of nutrients and soil out of the system. Therefore, the presence of agronomic practices protects and reduce the removal of nutrient and soil from erosion and leaching or increase nutrient inputs through nitrogen fixation (Nair, 1993). By saying turnover, it indicates how agronomic practices initiate the nutrient cycling. The multipurpose trees having a deep root takes the nutrients from down soil horizons and accumulate on the surface when the fallen litter decompose. By doing so, it also protects the nutrients from leaching. The catalytic indicate the process of physical, chemical, microclimatic and biological contribution for improvement of soil properties, moderation of the effect of acidity/salinity/alkalinity, an ameliorative effect on extreme conditions and their effect on soil microorganism and improvement of litter quality with increasing the species diversity (Nair, 1993).

Agronomic practice improves the soil physical conditions by the maintenance of soil properties (structure, porosity, moisture retention capacity and permeability) and through a combination of maintenance of organic matter with the effects of roots (breaking up of compact layers by roots). In addition, there is a modification of extremes of soil temperature through a combination of shading by canopy and litter cover (Young, 1989). In the parkland practice, Faidherbia albida is one example of an important tree that increases the soil-improvement including nutrient cycling and crop yield in Malawi and in Ethiopia (Buck et al., 2007). 
Table 3. The impact of some agronomic soil and water conservation measures on grain yield of crops $\left(\mathrm{kg} \mathrm{ha}^{-1}\right)$

\begin{tabular}{lll}
\hline No & SWC Practices & Yield mean difference $\left(\mathrm{kg} \mathrm{ha}^{-1}\right)$ \\
\hline 1 & Mulching & 629.2 \\
2 & Farm Yard Manure (FYM) & 3917.9 \\
3 & Compost & 782.9 \\
\hline
\end{tabular}

Source: Zenebe et al. (2015).

Large areas in the tropics are affected by salinity, alkalinity, acidity and waterlogging. And a great contribution of agroforestry can be seen also how the multipurpose trees in agronomic practices alleviate and maintain such tropical problems. For example the various species of Sesbania spp. can grow successfully in saline, alkaline, and even waterlogged soils (Steppler \& Nair, 1987). In Peru, where the soil is affected by high acidity and Al toxicity, annual crops did not produce economic yields beyond two or three years without applications of lime and fertilizer. However, hedgerow intercropping maintained yields of Al-tolerant rice and cowpea crops vary considerably, for many seasons. The same was true for Indonesia and Burundi (ICRAF, 1995; Palm, 1995).

\section{Conclusion}

An agronomic practice contributes high in the long term agricultural sustainability and sustainable agricultural farming. This paper reviews the major agronomic practices and their role in soil and water conservation. The major agronomic soil and water conservations practices in Ethiopia are strip cropping, mixed cropping, intercropping, fallowing, mulching, contour ploughing, crop rotation, conservation tillage and agroforestry. The plant canopies, litter and mulching intercept rain by decreasing the amount, intensity and the spatial distribution of the precipitation reaching the soil surface and this protects the soil surface from the direct impact of raindrops which can cause a splash and sheet erosion. In soil and water conservation, agronomic practice is higher than others, because crops and leguminous woody perennials in agronomic practice improve and enrich soil conditions by atmospheric nitrogen fixation, an addition of organic matter through litterfall and dead and decaying roots, nutrient cycling, modification of soil porosity and contribution to infiltration rates. It also alleviates and maintains salinity, alkalinity, acidity and water logging problems. Hence, the use agronomic practices for soil and water conservation is vital for climate change adaptation and mitigation because it can give both productive role (producing food, fodder, fuel, wood) and protective role (soil conserving functions, windbreaks and shelterbelts).

\section{References}

Ailincai, C., Jitareanu, G., Bucur, D., Ailincai, D., \& Zbant, M. (2009). Evaluation of the long-term effect of crop rotation on water runoff, soil and nutrient losses in the Moldavian Plateau. Cercetări Agronomice în Moldova, XLII(1), 19-29.

Andersen, M. K. (2005). Competition and complementarity in annual intercrops-The role of plant available nutrients (Ph.D. thesis, Department of Soil Science, Royal Veterinary and Agricultural University, Copenhagen, Denmark).

Araya, T., Cornelis, W. M., Nyssen, J., Govaerts, B., Getnet, F., Bauer, H., ... Deckers, J. (2012). Medium-term effects of conservation agriculture based cropping systems for sustainable soil and water management and crop productivity in the Ethiopian highlands. Field Crop Res., 132, 53-62. https://doi.org/10.1016/ j.fcr.2011.12.009

Barbier, E. B., \& Bishop, J. T. (1995). Economic values and incentives affecting soil and water conservation in developing countries. Journal of Soil and Water Conservation, 50(2), 133-137. https://doi.org/10.3368/ le.86.4.645

Biamah, E. K., Rockström, J., \& Mutuli, D. A. (2000). Transition to conservation tillage: Critical issues and options for Kenya. In E. K. Biamah, J. Rockström, \& G. E. Okwach (Eds.), Conservation Tillage for Dryland Farming. Technological Options and Experiences in Eastern and Southern Africa (Workshop Report No. 3, pp. 36-39). RELMA.

Birru, O., Quraishi, S., \& Bedadi, B. (2012). Effects of straw mulch and farmyard manure on run-off, erosion, in-situ water conservation, and yield and yield components of wheat at the highlands of Bale, south eastern Ethiopia. Afr. J. Agric. Res., 7(44), 5879-5886. https://doi.org/10.5897/AJAR12.1467 
Buck, L. E., Gavin, T. A., Uphoff, N. T., \& Lee, D. R. (2007). Scientific assessment of ecoagriculture systems. In S. J. Scherr, \& J. A. McNeely (Eds.), Farming with nature: The science and practice of ecoagriculture. Island Press, Washington, DC.

Burgers, P., Ketterings, Q. M., \& Garrity, D. P. (2005). Fallow management strategies and issues in Southeast Asia. Agriculture, Ecosystems \& Environment, 110, 1-13. https://doi.org/10.1016/j.agee.2005.04.010

Deborah, D. (2003). Soil and Water Conservation with a Focus on Water Harvesting and Soil Moisture Retention (pp. 11-17). A study guide for Farmer Field Schools and Community-Based Study Groups. FARMESA, Harare, Zimbabwe.

FAO. (1984). Guidelines: Land Evaluation for Rainfed Agriculture. FAO Soils Bulletin 52.

FARM-Africa. (2005). Practices in Wolaita Zone, Southern Ethiopia: Learning from Farmers. FARM-Africa, Ethiopia.

Garrity, D. A., Okono, M. G., \& Parrott, S. (2006). World Agroforestry into the Future. Nairobi: World Agroforestry Centre.

Garrity, D. P., Stark, M., \& Mercado, Jr. A. (2004). Natural Vegetative Strips: a bioengineering innovation to help transform smallholder conservation (pp. 263-270). Science Publishers Inc. Enfield, USA.

ICRAF. (1995). ICRAF Annual Report. Nairobi: ICRAF.

Jonsson, L. O., Singish, M. A., \& Mbise, S. M. E. (2000). Dryland farming in Tanzania. Experiences from the Land Management Program. In E. K. Biamah, J. Rockström, \& G. E. Okwach (Eds.), Conservation Tillage for Dryland Farming. Technological Options and Experiences in Eastern and Southern Africa (Workshop Report No. 3, pp. 96-113). RELMA.

Josh, M., Andy, B., Sego, J., David, M., \& Holly, W. (1999). The Relationship between Soil and Water. How Soil Amendments and Compost Can Aid in Salmon Recovery (pp. 98-104). King County Department of Natural Resources; Seattle, Washington.

Kariaga, B. M. (2004). Intercropping Maize with Cowpeas and Beans for Soil and Water Management in Western Kenya (Paper No. 993). Department of Geography and Environment Science, Monash University, Johannesburg, South Africa.

Kassie, M., Zikhali, P., Pender, J., \& Kohlin, G. (2010). The Economics of Sustainable Land Management Practices in the Ethiopian Highlands. Journal of Agricultural Economics, 61(3), 605-627. https://doi.org/ 10.1111/j.1477-9552.2010.00263.x

Kato, E., Ringler, C., Yesuf, M., \& Bryan, E. (2009). Soil and Water Conservation Technologies: A Buffer against Production Risk in the Face of Climate Change? Insights from the Nile Basin in Ethiopia (IFPRI Discussion Paper 00871).

Kilewe, A. M., Kealey, K. M., \& Kebaara, K. X. (1988). Agroforestry Development in Kenya. Proceedings of the Second Kenya National Seminar on Agroforestry November 1988 (p. 534). Nairobi, Kenya, ICRAF.

Lal R. (1975). Role of mulching techniques in tropical soil and water management. IITA Technical Bulletin No. 1 (p. 38). Ibadan, Nigeria.

Lal, R. (1998). Mulching Effects on Runoff, Soil Erosion, and Crop Response on Alfisols in Western Nigeria. Journal of Sustainable Agriculture, 11(2/3), 135-154. https://doi.org/10.1300/J064v11n02_10

Lynden, G. W. J. V., \& Lane, M. (2004). Soil and Water Protection using Conservation Tillage in Northern and Central Europe (p. 418). ISCO 2004-13 ${ }^{\text {th }}$ International Soil Conservation Organization Conference, Brisbane.

Mati, B. M. (2005). Overview of water and soil nutrient management under smallholder rainfed agriculture in East Africa (Working Paper 105). Colombo, Sri Lanka: International Water Management Institute (IWMI).

Meine, V. N., \& Bruno, V. (2000). Soil and Water Conservation (Lecture Note 3, p. 16). International Center for Research in Agroforestry (ICRAF), Bogor, Indonesia.

Milder, J. C., Majanen, T., \& Scherr, S. T. (2011). Performance and potential of conservation Agriculture for climate change adaptation and mitigation in Sub-Saharan Africa. WWF-CARE Alliance's Rural Futures Initiative. CARE: Atlanta, GA.

Morgan, R. P. C. (2005). Soil erosion and conservation (3rd ed., p. 315). Blackwell Science Limited, England. https://doi.org/10.1111/j.1365-2389.2005.0756f.x 
Nair, P. K. R. (1993). An introduction to agroforestry. Kluwer Academic Publisher with Cooperation ICRAF, Dordrecht, London. https://doi.org/10.1007/978-94-011-1608-4

Noordwijk, M. V., \& Verbist, B. (2000). Soil and Water Conservation (p. 16). International Centre for Research in Agroforestry, Bogor, Indonesia.

Palm, C. A. (1995). Contribution of agroforestry trees to nutrient requirements of intercropped plants. Agrofor. Syst., 30, 105-124. https://doi.org/10.1007/BF00708916

SCRP (Soil Conservation Research Programme). (2000). Area of Anjeni, Gojjam, Ethiopia: Long-term monitoring of the agricultural environment 1984-1994. Soil Erosion and Conservation Database, Soil Conservation Research Programme. Bern: Centre for Development and Environment (CDE).

Simpson, L. A. (2010). A Manual of Soil Conservation and Slope Cultivation. Caribbean Agricultural Research and Development Institute (CARDI), Ministry of Economic Development, Belize.

Tidemann, E. M. (1996). Watershed Management. Guidelines for Indian Conditions. New Delhi: Omega Scientific Publishers.

UNCCD (United Nations Convention to Combat Desertification). (2004). A carrying pillar in the global combat against land degradation and food insecurity. Background Paper for the San Rossore Meeting 'Climate Change: A New Global Vision', Pisa, Italy, 15-16 July 2004. UNCCD Secretariat.

Wood, P. J., \& Burley, J. (1991). A Tree for All Reasons: Introduction and Evaluation of Multipurpose Trees for Agroforestry (p. 167). International Centre for Research in Agroforestry, Nairobi, Kenya.

Young, A. (1989). Agroforestry for soil management. CAB International with Cooperation ICRAF, Nairobi, Kenya.

Zeleke, G. (2010). A Study on Mountain Externalities in Ethiopia: Final report. Addis Ababa, Ethiopia.

Zenebe, A., Simon, L., Robyn, J., Wolde, M., \& Tilahun, A. (2017). Impacts of Soil and Water Conservation Practices on Crop Yield, Run-off, Soil Loss and Nutrient Loss in Ethiopia: Review and Synthesis. Environmental Management, 59, 87-101. https://doi.org/10.1007/s00267-016-0776-1

\section{Copyrights}

Copyright for this article is retained by the author(s), with first publication rights granted to the journal.

This is an open-access article distributed under the terms and conditions of the Creative Commons Attribution license (http://creativecommons.org/licenses/by/4.0/). 